\title{
(Un)translatability revisited: transmetic and intertextual puns in Viktor Pelevin's Generation "P" and its translations
}

\author{
Roman Ivashkiv \\ University of Illinois at Urbana-Champaign, USA \\ roman904@illnois.edu
}

\begin{abstract}
Babylen Tatarsky, the protagonist in Russian writer Viktor Pelevin's novel Generation " $P$ " (translated into English by Andrew Bromfield as Homo Zapiens), works to adapt American advertisements for the Russian market and witnesses how the reality of Russia's tumultuous 1990s is replaced by a consumer-driven television simulation. Puns in the advertising slogans that Tatarsky translates, interspersed throughout the novel, are central to its plot. Some of these puns exhibit greater sophistication than others: in addition to utilizing homonymy, homophony, homography, paronymy, and polysemy, they involve transmesis, multilingualism, and intertextuality. This article compares how Pelevin's translators (English, German, Polish, Spanish, and French) approached these difficult puns. The objective of this comparative analysis is to demonstrate how the intertext(s) evoked through wordplay may, on the one hand, impede translation, but, on the other, open avenues for creative solutions, by producing new traces and echoes of meaning that make the act of translation possible. The issues raised by the various translations point to a need to re-examine the roles and tasks of the translator and underscore the importance of keeping the (un)translatability debate open. Ultimately, this article aims to contribute to the ongoing reconceptualization of what literary translation is and, especially, what it does: with texts, readers, literatures, and, above all, with language.
\end{abstract}

Keywords: wordplay, puns, untranslatability, transfiction, transmesis, multilingualism.

\section{Introduction}

The translation of wordplay has been the focus of many studies involving different languages, literatures, and time periods, yet remains a controversial issue and, perhaps, one of the most daunting challenges for the literary translator. Paradoxically, while puns are often deemed untranslatable (see Jakobson 2000 [1959]), some contemporary translation scholars (see Delabastita 1993, 1996, 2004) claim that all puns are to some degree translatable. 
Whereas examples of their successful translation abound, blatant omissions of puns in translations of fiction unfortunately (as this article will demonstrate) still happen often.

This article enters the debate with examples from Slavic literature, examining the more complex puns in Viktor Pelevin's novel Generation " $P$ " and in its English, Polish, German, Spanish, and French translations. What makes the discussion of puns in Generation " $P$ " especially noteworthy is the novel's transmetic mode. Transmesis, or mimesis of translation, is Thomas Beebee's (2012) term for the fictional portrayal of translators and translation, both as process and product, and Generation " $P$ " can be viewed as a transmetic novel. It is written in a hybrid manner with frequent code-switching between Russian and English. Translation is one of its major themes as translation issues are woven into the plot. The protagonist Tatarsky is a translator-copywriter who adapts American advertisements to the Russian market.

Moreover, the protagonist is an avid punster, and wordplay in Generation " $P$ " is central to much of the humour in the novel. Some of Pelevin's puns are more sophisticated because in addition to utilizing homonymy, homophony, homography, paronymy, and polysemy, they are also premised on transmesis, multilingualism, and intertextuality. In posing serious challenges for translators, these puns offer a new ground for the discussion not only of translation strategies but also, more importantly, of (un)translatability as a practical, theoretical, and philosophical problem.

My objective is to analyse how some key transmetic and intertextual puns in the novel have been rendered in English, and to compare the approaches of Pelevin's English, German, Polish, Spanish, and French translators. This comparative analysis will allow me to then explore how the intertext(s) evoked through puns may, on the one hand, impede translation but may also, on the other, open avenues for creative solutions by producing new traces and echoes of meaning that in fact make the act of translation possible. The issues raised in the article will point to a need to re-examine the roles and tasks of the translator beyond just conveying "meaning." The importance of continuing (rather than resolving) the (un)translatability debate will also be underscored, because keeping it alive prevents translation from turning from an art into a craft and challenges practitioners to experiment and innovate.

Structurally, the article is divided into five sections. Following this introduction, in section two, I give an overview of the pun as a literary trope and recount the major theoretical postulates on the translation of wordplay. Section three provides a more detailed context for Pelevin's novel and emphasizes the important role of transmetic and intertextual puns in it. Section four examines the most representative examples of these puns by discussing their possible interpretation and comparing how Pelevin's translators - Andrew Bromfield (English), Ewa Rojewska-Olejarczuk (Polish), Andreas Tretner (German), José Manuel Prieto (Spanish), and Galia Ackerman and Pierre Lorrain (French) - worked with them in their versions. Finally, section five, the conclusion, steps back from the examination of the puns to offer a broader theoretical discussion of the problem of (un)translatability, addressing some of its causes and corollaries, and paying special attention to omissions, translation ethics, and the problem of linguistic and cultural hegemony.

Conceptually, the article is situated within the "fictional turn" in translation studies, which sees fiction as one of the possible sources of knowledge about translation. In other words, the fictional portrayal of the punning translator Tatarsky and his work on translation projects has the potential to inform our thinking about translation in real life. Methodologically, the article relies on comparative translation analysis and follows an inductive trajectory, whereby specific examples of puns in translation shed light on broader theoretical and philosophical issues. Its 
contribution lies not only in the multilingual comparison (an approach that, despite its potential, is employed too rarely in considering untranslatability), but also in its application of transfiction (fiction about translation) to advancing translation theory. Wordplay in puns is an extreme case of poetic language, and its creative handling in translation casts new light on the roles and tasks of the translator, underscoring the importance of continuing (rather than closing) the (un)translatability debate. Ultimately, the article calls for and contributes to the reconceptualization of what literary translation is and, especially, what it does: with texts, readers, literatures, and, above all, with language.

\section{The pun: a controversial and (un)translatable trope}

"In the beginning was the pun," writes Samuel Beckett (2009:43) in his novel Murphy. Literary scholar Jonathan Culler (1988: 4) unpacks Beckett's maxim in the "The Call of the Phoneme," an introduction to his seminal edited collection, in which he elucidates why the pun is "the foundation of letters." Known more broadly as "a play on words" or under the less common term of Greek origin "paronomasia," the pun is a controversial literary trope, which evades straightforward definition ${ }^{1}$, defies classification ${ }^{2}$, and often provokes mixed attitudes. Its opponents believe it is a primitive form of humour that tends to elicit groans rather than laughter (see Ulmer (1988), Blake (2012: xi), Kjerkegaard (2011), and Gruner (1997: 131). Even Sigmund Freud (2002 [1905]: 37) does not speak highly of puns. Referring to them as "Kalauer" or "calembourgs" (sic), he calls puns "the lowest kind of dwelling-place [for wit], probably because they are the 'cheapest' and can be made with very little trouble", a surprising criticism given the connection between the pun and parapraxis (i.e. the Freudian slip). More recently, Joseph Tartakovsky (2009: A21) has expressed similar scepticism in his New York Times op-ed entitled "Pun for the Ages," comparing the longevity of puns with that of fruit flies. Despite its argument that "puns are the feeblest species of humour because they are ephemeral," Tartakovsky's own piece brims with both punny and puny jokes as the author arrives at the verdict that "[p]unning ... like every non-deadly sin, is easier to excuse than to resist."

Linguist and literary theorist Roman Jakobson (2000 [1959]: 118) valorises the pun in his influential and widely anthologized essay "On Linguistic Aspects of Translation," where he proclaims that the pun "reigns over the poetic art." Based on that claim, he also concludes that

\footnotetext{
${ }^{1}$ Definitions are often broad and lack precision. According to the OED, the pun is " $[t]$ he use of a word in such a way as to suggest two or more meanings or different associations, or of two or more words of the same or nearly the same sound with different meanings, so as to produce a humorous effect; a play on words." Wordplay is defined as "(a) the action of playing with words; witty use of words, esp. of verbal ambiguities; (b) an instance of this, a play on words..., a pun." The two terms pun and wordplay may thus be used as synonyms, even though the latter is an umbrella term. Delabastita (1996-127) defines wordplay as "the general name for the various textual phenomena in which structural features of the language(s) are exploited in order to bring about a communicatively significant confrontation of two (or more) linguistic structures with more or less similar forms and more or less different meanings."

${ }^{2}$ According to Molly Mahood and Evan Esar (qtd. in Redfern 1985: 5), the varieties of wordplay are infinite. Among many others, as (Partington 2006: 111) illustrates, they include "blendings, reversals, chiasmus, zeugma, anagrams, malapropisms, Tom Swifties (or Wellerisms), resegmentation or metanalysis, reverse coinages, and "notas-they-seems."
} 
"poetry is by definition untranslatable" (2000[1959]: 118). Paradoxically ${ }^{3}$, Jakobson follows this dictum with a solution, "creative transposition," offering this caveat: "If we were to translate into English the traditional formula Traduttore, traditore as 'the translator is the betrayer,' we would deprive the Italian rhyming epigram of all its paronomastic value" (Jakobson 2000 [1959]: 118). It is unclear why Jakobson chose to discuss, even if hypothetically, a deliberately awkward translation, disregarding a much more symmetrical option "Translator traitor." In any case, this example, while echoing the oft-lamented untranslatability of puns, serves to illustrate their complexity. Not every language may possess the resources to capture the concinnity (and the punch) of the Italian adage, which is contained both in its content and in its form.

There are various explanations for why puns are often considered untranslatable. Derek Attridge (2009: 9) discusses the "insubordination displayed by the pun" while Blasing (1995: 174) offers a psychoanalytic justification, according to which puns are "motivated figures ... [that] do not enter a symbolic economy or recognize the "metaphysical' values." Quoting Suzanne Jill Levine's idea that "the most difficult untranslatables are words themselves," Val Vinokur and Rose Réjouis (2018: 18) argue that "the notion of untranslatability could actually represent a defensive attitude, in that it sanctifies the internal quirks and confusions of a language..." Even so, if Koestler's (1964: 64-65) idea that the pun is "the bisociation of a single phonetic form with two meanings - two strings of thought tied together by an acoustic knot" is correct, the reasons why this "formal" knot cannot be easily untied and retied in a different language lie in the five phenomena that contribute to wordplay: homonymy, homophony, homography, paronymy, and polysemy. Consequently, translators are confronted with multiple challenges in accomplishing their task:

a) to capture the tension between form/sound and meaning (it is this tension that produces the effect - often, though not necessarily, humorous);

b) to account for linguistic and cultural asymmetries between two (or more) languages;

c) to deal with constraining differences in context, to preserve playful ambiguity without giving explicit preference to one reading/interpretation;

d) to operate within a comparable level of economy or structure (often restricts them to one word or word combination).

It is, in many cases, these aspects of the "fetishization of the word" (a concept I borrow from my colleague Timothy Sergay) ${ }^{4}$ that makes puns seem untranslatable. Additionally, with puns, the problem often comes down, metaphorically speaking, to the "unaffordability" of using an extra word.

One of the most comprehensive and authoritative refutations of the untranslatability of puns can be found in Delabastita (1993: 171-190), where he stresses that translatability is "a relative [rather than] a binary or absolute category" (183) and adds that:

\footnotetext{
${ }^{3}$ Brian Baer (2011: 175) points out that while Jakobson's essay “opens with a bravado statement on the possibility of translating any content, it ends on a note of despair regarding the possibility of translating literary and in particular poetic form."

${ }^{4}$ Timothy Sergay is a scholar and translator of Russian and he teaches at State University of New York at Albany. $\mathrm{He}$ expressed this at idea at the panel on Translation and Ideology at the 2018 conference of the American Association of Teachers of Slavic and East European Languages in Washington, DC. Examples of fetishization of the word can be found in Sanders (2014), who offers a collection of untranslatable concepts/words from different languages but effectively provides explanations right under them.
} 
[o]ne of the reasons why traditional theories of translation are so keen to declare wordplay untranslatable is the fact that translators of wordplay often turn out to resort to allegedly dubious translation relationships such as low-equivalence substitution (the pun is "adapted"), deletion (the pun is dropped in the T.T.), addition (new puns are introduced), permutation (the T.T. contains wordplay but in different textual positions), or repetition (the S.T. pun is simply quoted in a footnote).

(Delabastita 1993: 188, my emphasis)

In his "Introduction" to the special issues of The Translator on wordplay in translation, which he edited, Delabastita (1996: 134) offers a more elaborate yet essentially similar list of eight possibilities, which are referred to as "a wide range of translation methods." Listed as bullet points, they are: "pun-pun, pun-no pun, pun-related rhetorical device, pun-zero, pun st-pun tt, no-pun-pun, zero-pun, editorial techniques" (Delabastita 1996: 134). Although this list of translation approaches or outcomes may be useful in outlining the translator's options, it is not entirely clear if they can be regarded as methods per se because methods address the "how?" rather than merely listing the "what?" Delabastita's list, in describing translation as a product, sheds less light on the process, which - especially in the case of puns - often remains as spontaneous, serendipitous, and intuitive as any process of creative writing.

Despite Derrida's renowned provocative claim about the simultaneous necessity and impossibility of translation (Derrida 1985: 171), the French philosopher nevertheless believed in translatability but had one important reservation, according to Kathleen Davis. In an illuminating essay, entitled "Signature in translation," Davis (1997: 40) explains Derrida's position on the translatability of wordplay by unpacking his concepts of signature, iterability, and citationality. She concludes that "[w]ordplay... even though it is the signature of a language, is nonetheless iterable and therefore accessible to recognition and citation by another language" (1997:40). In her last paragraph, she quotes a phrase from Derrida's Shibboleth for Paul Celan in which he asserts that "[e]verything seems in principle, by right, translatable except for the mark of the difference among the languages within the same poetic event" (Davis 1997: 40). Pelevin's novel Generation " $P$ " is an example of such a "poetic event" and contains a crucial transmetic example of such a mark of difference among the languages.

\section{Pelevin's transmetic novel Generation "P": does the $P$ stand for pun?}

Although Viktor Pelevin is one of the most well-known, prolific, and translated contemporary Russian writers, his penchant for puns, particularly prominent in his 1999 novel Generation " $P, " 5$ has not always been praised or appreciated, despite the novel's general critical acclaim. For example, in Pokoleniie Pustoty [A Generation of Emptiness], Sergei Polotovskii and Roman Kozak (2012: 163, my translation from Russian) praise Pelevin, with a tad of irony, as "a champion, among contemporary writers, of playing with words, a grandmaster of transparent allusions and crude approximations." They then suggest, more negatively, that Pelevin resorts to so-called "domashnie zagotovki" (i.e. set pieces, or plain stand-up-comedy jokes prepared in advance and inserted into the text with no special purpose). Regardless of the validity of this

\footnotetext{
${ }^{5}$ The unintended $\mathrm{p}$ alliteration in this sentence, at least in English, may suggest yet another interpretation of the titular "P," whose different readings range from Pepsi to Pelevin to pustota (emptiness) to the more pungent though less probable polnyi pizdets (complete fucking disaster) in Russian.
} 
assessment, the importance of puns in Pelevin's novel is undeniable. The protagonist Babylen Tatarsky, a copywriter who adapts American advertisements to the Russian market and eventually heads an organization that simulates reality by controlling the entire television industry, is himself an avid punster. The advertising slogans he translates (or creates through adaptation), as well as both his and the omniscient narrator's self-reflexive and metatextual comments about translation, are often steeped in wordplay.

As I have argued elsewhere, Generation " $P$ " is a transmetic novel that, "in its portrayal of the process of localization and by repeatedly 'performing' translation in footnotes and parenthetical explanations, wrestles with cultural and linguistic untranslatability and reiterates the profoundly intertextual, playful, and creative nature of translation" (Ivashkiv 2018: 201). Many of the puns in the novel are transmetic (i.e. premised on the portrayal of translation), multilingual (i.e. involving the use of different languages or code-switching, primarily to and from English) and intertextual (i.e. alluding to other texts and cultures). These three features of puns in the novel undoubtedly complicate the task of translation. In his review of Sorokin's and Pelevin's novels, Goluboe Salo and Generation “P," scholar and critic Mark Lipovetsky argues that:

[d]espite the success of all Pelevin's previous novels in English translation, the translation of Generation " $P$ " could hardly be adequate. After all, the novel is written in a fantastical mix of Russian and English, in which the same text or even simply a word is imbued with a double meaning by virtue of its double status, thereby becoming a metaphor.

(Lipovetsky, 1999: section 7, my translation)

Even without considering what Lipovetsky meant by "adequate" translation, his statement reflects the complexity that confronted Pelevin's translators when dealing with this bilingual text written in a Volapük [constructed language, a precursor of Esperanto, to borrow Irina Rodnianskaia's words] which is not only inherently hybrid but also laden with intertextual and transmetic wordplay.

\section{A comparative analysis of puns in Generation "P" and its translations}

The first example of a pun comes from the opening paragraph of Chapter 3 , in which the omniscient narrator explains developments in Russian advertising after the collapse of the Soviet Union. Tatarsky's former classmate Morkovin has just convinced him to become a copywriter and instructed him that in Russia, unlike in the West, the copywriter must first brainwash the client before the client can brainwash the consumer. Thanks to that advice, Tatarsky's first assignment is unexpectedly successful and almost makes him a fortune; soon, however, his assignments become infrequent as more advertising agencies with full-time staff copywriters appear. The narrator claims that these advertising agencies proliferated and that, in one of his advertising concepts, Tatarsky reflected on their increasing but also fleeting popularity:

Эти агентства множились неудержимо - как грибы после дождя или, как Татарский написал в одной концепции, гробы после вождя. (665, my emphasis) 
This sentence can be translated literally as "These agencies multiplied uncontrollably, like mushrooms following rain or, as Tatarsky wrote in one concept, like coffins following the leader." Although this verbatim translation is stylistically awkward, requires background cultural knowledge, and obscures the reason why Tatarsky felt compelled to rewrite the original simile, its overall message is clear. In Russian, the second expression (highlighted in bold) does not only mockingly allude to the fact that the passing of Soviet dictators was normally followed by purges in their cliques (e.g. after Lenin's death Stalin effectively exterminated most potential rival successors) but also plays with the form. The two similes bear a close phonetic similarity, with only two letters making the difference: "kak griby posle dozhdia" ("like mushrooms following rain") and "kak groby posle vozhdia" ("like coffins following the leader").

Surprisingly, in the English, Spanish, and French translations, the entire opening paragraph including the coffin pun is missing. In Rojewska-Olejarczuk's Polish translation, we read, "Agencje te wyrastały jak grzyby po deszczu przy drodze lub - tak to ują Tatarski w jednej ze swych koncepcji - jak areszty i groby za wodzem" (33, my emphasis, in my verbatim gloss, "These agencies grew up like mushrooms by the road after the rain or - as Tatarsky put it in one of his concepts - as arrests and graves after the leader"). The pun is here less catchy and areszty (arrests), absent in the original, is added to clarify the coffins. Polish, as a cognate Slavic language, allows for phonetic similarity between grzyby/mushrooms and groby/coffins.

The most creative and playful solution in the five translations was found by Tretner, whose German reads, "Solche Agenturen schossen wie Pilze aus dem Boden - oder wie Spermien aus den Hoden (diesen Kalauer hatte Tatarski in einer seiner Konzeptionen stehen" (33, my emphasis, in my verbatim gloss, "Such agencies sprang up like mushrooms - or like sperm from the testicles (this pun Tatarsky had used in one of his concepts)."). Tretner plays with German expressions for "like mushrooms from the ground" and "like sperm from the testicles," to exploit the Boden (ground)/Hoden (testicles) similarity. Although he had to relinquish the part of the joke referring to Soviet purges, Tretner has created a pun that, with its vivid sexual image, captures the main idea of proliferation.

The second example of a complex pun, also from Chapter 3 , is a more extreme case of transmetic wordplay, a translingual pun based on Tatarsky's fictional performance of an act of translation. When Tatarsky learns that he is to work as a freelancer, an unusual mode in early 1990s Russia, the narrator has Tatarsky make a clever reflection on the translator's low pay:

Работа была free lance - Татарский переводил это выражение как «свободный копейщик», имея в виду прежде всего свою оплату. (Pelevin 2003: 665)

The work was "freelance" - Tatarsky used the term as though it still had its original sense, having in mind first of all the level of pay. (Bromfield 2002: 19)

Capturing the Russian pun requires the visibility of the act of translating, for the original Russian presents the English word then continues, "Tatarsky translated this expression as...," making the act of translation very present. In Bromfield, translation as act almost vanishes, as Bromfield avoids the multilingual aspect and simply writes, "Tatarsky used the term as." In Russian, the pun goes on to exploit the ambiguity of the word копейщик (kopeishchik), literally "lance knight" which holds a further, intentionally "incorrect" and humorous sound-relationship. The word "lance" in Russian is коnьe, kop'e, and so the word "freelancer" or "lance knight" (konейщик, kopeishchik) also echoes the word копейкa (kopeika, "penny”). Kopeishchik, then, 
can be interpreted as the person who makes only pennies. Because English is the language from which Tatarsky translates the word in Russian, Bromfield-writing his entire sentence in English - had to come up with a different basis for a pun. The humorous implication of his pun, only weakly captured in the English word free, is that translators often find themselves working for a pittance or for free.

Tretner's German rendition of this pun is similar to Bromfield's except that he retains the word translated in the sentence, and the word "freelance," which he can do without compromising the logic of the sentence in translating it into German. He writes, "Der Job war freelance - ein Ausdruck, den Tatarski für sich mit 'freier Landsknecht' übersetzte - besonders, wenn er an die Bezahlung dachte" (34). Tretner exploits the real historical meaning of freelancer and comes up with Landsknecht, a European mercenary foot soldier of the $16^{\text {th }}$ century armed with a pike. Although it is not clear if the word Landsknecht suggests low pay, the image of a mercenary foot soldier may connote poverty and financial opportunism.

In Polish, Rojewska-Olejarczuk coins (no pun intended!) the word kopiejkorób (pennymaker) and maintains the English word "freelance." She writes, "była to robota freelance Tatarski tłumaczył ten zwrot 'niezależny kopiejkorób', mając na myśli przede wszystkim swoje wynagrodzenie" (34), and adds a footnote to explain the untranslatable play on pennies: "Ros. kopiejszczik, nieprzetłumaczalna gra słów: freelance - niezależny dziennikarz, znaczy dosłownie 'najemny żołnierz, kopijnik'; kopiejszczik to zarazem 'kopijnik' i 'ciułacz' (przyp. tłum.)” (34). Prieto's Spanish translation omits the reference to Tatarsky having translated the term "freelance," keeping the English word, but without making a pun: "El trabajo era free lance" (31). In the French translation, both sentences are omitted, which is a surprising decision because this pun is not simply a random witticism but a trope that defines one of the novel's key themes.

The third example of an extreme pun combines a relatively simple pun based on polysemy with a more esoteric intertextual pun. It comes from an episode in Chapter 11, in which Tatarsky's friend Morkovin introduces him to Azadovsky, head of a secret organization that controls the television industry and simulates reality. Not to attract unnecessary attention from the general public, the sign on the building reads "The Institute of Apiculture," and to prove to Tatarsky that the connection to bees, even if tenuous, does exist, Azadovsky invites the two friends to join him on the carpet, which is covered with cocaine. When Morkovin and Tatarsky enter, Azadovsky invites them to sit down, using a Russian verb that can also mean "to become addicted/to get hooked on something." Azadovsky says, "Подсаживайтесь / Podsazhivaites" and Morkovin replies, “Давно подсели / Davno podseli" (798). The second meaning of the invitation, that of becoming addicted, is humorous given the cocaine-covered carpet.

This pun may be captured in other languages by creating a situational ambiguity using another idiom. However, Bromfield offers an explicatory translation in English: "Join the club / We're old members" (150), which does convey the overall message but loses the figurative meaning of the original pun. Writer and translator Erín Moure suggested wordplay regarding hooking rugs along the lines of "'Sit down.' "Me and that rug are already hooked." In Rojewska-Olejarczuk's Polish version, Azadovsky invites Morkovin and Tatarsky to lie down and they respond that they've been lying for a long time already, which does create a wry ambiguity: "Połóżcie się - przemówił głuchym głosem. - Już od dawna leżymy - odpowiedział Morkowin" (198). In Tretner's German version, the invitation is to "settle down": "Laßt euch nieder" (202), and the response is the diffusely ambiguous "Aufs allgemeine Niveau!" (which can be translated verbatim as "On the general level"). Both the Spanish and the French translators adopt a similar strategy to Bromfield's and use expressions, which pun only weakly, 
for "joining the club." Interestingly, in the Spanish translation, Morkovin's retort includes a detail that is nowhere to be found in the original Russian, namely, that they have been members of the "sniffing club" for three years now ("Somos miembros desde hace tres años - contestó Morkovin" (177, my emphasis).

The episode continues. After they sit down, Tatarsky stares at Azadovsky's expensive Swiss watch, trying to impress the big boss by naming the brand, "Piaget Possession," and by quoting the price. When Azadovsky responds unenthusiastically, Morkovin tries to retort with a joke alluding to Georgii Daneliia's 1986 film Kin-dza-dza! Azadovsky, however, misses the allusion and the pun. The exchange in Russian goes as follows:

- Нравятся? - спросил он.

- Ещё бы, - сказал Татарский. - Если не ошибаюсь, «Piaget Possession»? Кажется, стоят семьдесят тысяч?

- Пеже позесьон? - Тот поглядел на циферблат. - Да, действительно. Не знаю, сколько стоят.

- Господин Пеже со своими пацаками, - сказал Морковин.

Хозяин кабинета явно не понял шутки. (798, my emphasis)

Bromfield's English translation, which is short the last two lines, reads,

'You like it?' he asked.

'Of course,' said Tatarsky. 'A Piaget Possession, if I'm not mistaken? I think it costs seventy thousand?'

'Piaget Possession?' The young man [sic, incorrect reference] glanced at the dial. 'Yes, so it is. I don't know how much it cost.' (151, my emphasis)

In Russian, Morkovin's pun relies on the closeness in pronunciation of Piaget and gospodin PeZhe (Mr. PeZhe), a character in Daneliia's film. This pun is omitted in all five translations, as is the last line of the original exchange in Russian, which says that Azadovsky apparently did not catch Morkovin's joke. Since the translations make no jokes, perhaps the translators felt there was no need to translate this addendum.

The fourth example of complex puns involves two allusive puns from the same paragraph at the beginning of Chapter 5, entitled "Poor Folk;" they carry great significance in the novel because they depict Tatarsky at work. According to the narrator, Tatarsky's experimentation with drugs had a positive effect on his creativity. Thanks to his slogan "The Motherland's \#1 Smoke!," Parliament beat Marlboro to became the most popular cigarette brand in Moscow. However, as new advertisements appeared, Tatarsky's "masterpiece" was quickly forgotten. This moment is described by a metaphorical cliché "kanut v Letu" (verbatim, "sink into the Lethe" or, more idiomatically, "vanish into thin air"). The Lethe is a river in Hades, and, according to Greek myth, those who drank from it became completely forgetful. In Russian, the expression is sometimes used to describe how something is gradually forgotten. The nominative case form of the river is Лema (Leta), while the accusative case used in the expression is Лemy (Letu). Letu differs from the Russian word for summer лemo (leto) only in the end vowel (i.e. u/o), which in final unstressed syllables can sound similar. Thus, the first pun in this passage is based on the play between the Russian words for Lethe and summer. The narrator says that the smoke of the motherland from Tatarsky's slogan "fell into the Lethe, or, more precisely, into winter." 
In Bromfield's English version, “'the smoke' of the Motherland' was dispersed without a trace into the thick gloom of winter" (my emphasis), an image captured similarly in the Spanish translation, where "el humo de la patria" fue disipado por la melancolía de un invierno" (57, my emphasis). The French translation follows a similar pattern, using oblivion instead of the Greek name for the river: "la fumée de la patrie tomba dans l'oubli, ou plutôt s'évanouit sans laisser de traces dans l'air froid de l'hiver, très précoce cette année-là" (63). Rojewska-Olejarczuk also incorporates the river image in Polish by explaining that the smoke was consumed by the river of oblivion: "Później jednak ojczyste dymy pochłonęła rzeka zapomnienia, a właściwie zima, która nadeszła zaskakująco wcześnie" (63). Tretner goes even further in German, not only avoiding mention of the Lethe but also incorporating a Latin proverb -from Ovid and Homer - in the sentence "Et fumus patriae est dulcis" ("and the smoke of fatherland is sweet"). As Pursglove (2008) explains, mention of the Lethe was once popular among Russian writers. Nevertheless, all the translations viewed here resort to a paraphrase/explication strategy for the scene, while Pelevin's pun, though it was almost caught in Tretner's more creative version, slips into the Lethe (pun intended).

The second wordplay in this intertextual pun sequence is even more complex, but it has found better fortune in translation. It is based on the phrase "s korablia na bal" (from ship to ball), mistakenly attributed in the novel - unclear whether Pelevin makes the mistake on purpose or simply falls prey to a common misunderstanding - to the Russian playwright Griboyedov. In fact, the phrase was Pushkin's, who was comparing his protagonist Eugene Onegin, in his eponymous verse novel, to Griboyedov's protagonist Chatskii in Woe from Wit. Pushkin's stanza from chapter 8 of Eugene Onegin talks of Onegin returning home and reads: "И путешествия ему, / Как все на свете, надоели / Он возвратился и попал, / Как Чацкий, с корабля на бал” (ту emphasis). In Charles Johnston's English translation, it reads: “... and soon his travels had begun, / as all things did, to bore him; homing, / like Chatsky, he arrived to fall / direct from shipboard into ball" (my emphasis). Pushkin's expression became a popular adage in Russian implying a sudden change of situation. Pelevin plays with the last word бал ( $b a l$, literally, ball as in a large formal gathering involving dance) by turning it into бля (blia, an interjection milder than fuck but stronger than shit), thereby repeating the last syllable in корабля (korablia) and achieving a perfect rhyme. A sexualized image of a long-legged girl that Tatarsky sees on the poster with the slogan justifies a reading in which the word blia may be suggestive of whore. Therefore, possible renditions of the second iteration could vary from "from ship to hip" to "from ship to shit" to "from ship to whore" which alters the usual expression "from ship to shore," while winking at a common shoreside activity of sailors. Bromfield's English translation of this passage reads:

The only dubious echo of the slogan left in the snowbound advertising space of Moscow was the phrase: 'From ship to ball', another borrowing - by an unknown colleague of Tatarsky's - from the poet Griboedov. It was to be glimpsed at one time on large hoarding advertisements for menthol cigarettes - a yacht, a blue sky, a peaked cap with sunburst and a pair of long legs. Tatarsky felt a pang of jealousy at this, but not a very powerful one - the girl in the menthol advert had been chosen to suit the taste of such a wide target group that the text seemed spontaneously to read as: 'From ship to balls'. (43)

Bromfield keeps the expression simple by staying close to the original, conveying the sense of crassness by playing with the polysemy of the word ball and its plural form balls (testicles). Rojewska-Olejarczuk's solution in Polish surprisingly outperforms the Russian original not only 
by capturing the playful tension between form and meaning but also by conveying the economy of the Russian expression. Her slogans read, respectively, "Ze statku na bal" ("From ship to ball") and "Na ostatku do lal" ("Lastly, to the dolls/chicks"). Tretner, for his part, might have interpreted the Russian "blia" differently. His German slogans read, respectively, "Vom Schiff auf den Ball" ("From ship to ball") and "Vom Schiff auf den Hund" ("From ship to the $\operatorname{dog}[\mathrm{s}]$ ") (63). Although I was unable to verify this, the second iteration may stem from the expression "auf den Hund gekommen," which means "to find oneself in a bad situation," similar to "going to the dogs" in English. Interestingly, Tretner also corrects the narrator's "mistake" by mentioning Pushkin in the German text (along with Griboyedov and the German title for Woe from Wit). In the Spanish and French translations, the original expression uses dance and party, respectively, while the pun then becomes "Del buque a las putas" ("from the ship to the whores"), a straightforward interpretation in Spanish, and a slightly more nuanced "Du bateau à la fesse" ("from boat to bum") in French.

The fifth (and final) example of a complex pun in Pelevin is the slogan Tatarsky creates after trying hallucinogenic mushrooms and almost losing his sanity. In a fit of delusion, he prays to God to repent for his behaviour. Imagining the Russian nouveau riche as his target audience, he offers to create a slogan for god and then plays with the words Iocnodb (Gospod [with soft d pronunciation, non-existent in English]) meaning "the Lord," and zocnod (gospod [hard d]), the genitive plural form of the Russian noun gentlemen. Sharing a common etymology and overlapping in semantic meaning, the two words differ only in the quality of the final sound д (d). My literal translation from Russian reads as follows:

Getting up with difficulty from his knees, Tatarsky dragged himself to the table, grabbed a pen and took a note in jerky spiderish handwriting:

Poster (plot for a clip): a long white limousine in the background of the Cathedral of Christ the Savior. Its backdoor open, light radiating from it. A sandal sticking out from the light, almost touching the asphalt, and a hand lying on the handle. Face can't be seen. Only light, car, hand, and leg. Slogan:

CHRIST THE SAVIOR

REPUTABLE LORD FOR REPUTABLE/GENTLEMEN/LORDS/SIRS

Variant:

\section{LORD FOR RESPECTABLE LORDS}

This translation, however, does little justice to the original pun in Russian. Bromfield, in the published English translation uses poetic license and reworks the whole episode by creating a new setting for the concept:

Managing somehow to scramble upright, Tatarsky struggled over to the desk, picked up a pen and began writing in a jerky, spiderish scrawl:

Poster (theme for a clip). A room in a very expensive hotel. Carrara marble table. A laptop computer flashes out a message: 'Transaction confirmed'. Near the computer we see a rolled-up hundred-dollar bill and a hotel-room Bible in three languages. Slogan:

THE SHINING WORD / FOR YOUR SHINING WORLD! 
Variant: another setting - a private jet airplane, a stock exchange, a Manhattan penthouse, a Côte d'Azur estate, etc. Instead of the Bible we see the Saviour Himself approaching the camera in the rays of his glory. Slogan:

\section{A FIRST-CLASS LORD / FOR YOUR HAPPY LOT! (123)}

Although both slogans created by Bromfield differ from the original Russian, they not only convey the parodied image of the Russian nouveau riche glamour, they also reflect the language play that Pelevin constantly teases out of his protagonist. In an interview for gazeta.ru, Pelevin stated that he usually goes over the translations of his works, adding that he had a difficult time with Generation " $P$ ":

I had to create most of the slogans from scratch in English because it was difficult to translate the Russian ones. This often entailed changing the entire piece around the slogan. For example, the translator suggested that "The Reputable Lord for Reputable Lords" be transformed into "The Sound Savior for the Sound Savers" or something along those lines. I didn't like it because the most important thing disappeared. As a result, I substituted the commercial of God for the commercial of the Bible. The clip then read thusly: [see Bromfield's translation quoted above]. This is an example of how a text is transformed in translation. But it is difficult to talk about some principles according to which these transformations occur. There are no principles here, only feelings. And Andrew Bromfield is an excellent translator

(par. 5-6, my translation)

Whereas Rojewska-Olejarczuk could stay close to Russian because the Polish word for Lord works similarly to the Russian one (e.g. "CHRYSTUS ZBAWICIEL SOLIDNY PAN DLA SOLIDNYCH PANÓW / Ewentualnie PAN DLA SOLIDNYCH PANÓW" (166), Tretner in addition to the first version of the slogan in German ("JESUS CHRISTUS / Ein solider Herr für solide Herren" (169) also cites the two English slogans from Bromfield. Although Tretner's approach fits with the storyline - as Tatarsky works with both Russian and English - this "surplus" of English in the German translation comes not from the Russian original but from another translation! While Ackerman and Lorrain (161-162) stick close to the original slogans and settings with only subtle modifications in French (i.e. "men of weight" and "powerful men"): "CHRIST SAUVEUR / UN SEIGNEUR SOLIDE POUR DES HOMMES DE POIDS. Variante: LE SEIGNEUR DES HOMMES PUISSANTS," the Spanish translation, like the German, relies on Bromfield's English rather than Pelevin's Russian. "iPALABRAS LUMINOSAS / PARA TU LUMINOSO MUNDO!” and “ ¿UN SEÑOR DE PRIMERA / PARA UN MUNDO DE PRIMERA!" (147), along with the description of new poster settings, read as if they were translated from Homo Zapiens rather than Generation "P."

\section{Conclusion}

My analysis of how the English, Polish, German, French, and Spanish translators of Generation " $P$ " deal with the "extreme cases" of poetic language (Attridge 2009: 9) that these five puns involve is not intended to provide empirical data to resolve the (un)translatability debate. To attempt to do so, as I have argued in the introduction, would not only be futile but also an 
unproductive pursuit. My purpose is rather to provide examples from multiple-language translations of one novel from Russian - a language that is more distant from English than many European languages - that offer grounds from which I can then revisit the most contentious issues and questions framing the debate.

As Delabastita suggests, (un)translatability is rarely (if ever) employed as an absolute term. Hermans (2003: 301) points out that it "rather questions whether fully adequate translation can be achieved" (my emphasis). The descriptor adequate, however, like many other terms that persist in reviews and scholarly discussions of translations, remains rather problematic and contradictory. Lipovetsky's doubt, quoted in Section 3, whether Generation " $P$ " can be adequately translated is not unjustified. His point, after all, was to underscore the complexity of the novel's language and its hybrid mode. Similarly, examination of the existing translations, if we focus only on the "yes/no" question of whether untranslatability exists, simply brings us back to the status quo. Some puns have been more or less effectively rendered in each of the five translations of Generation " $P$," regardless of whether they are in cognate or more distant languages, while some have been omitted or flatly explained away, losing the humour. In any case, whether the puns have been translated "adequately" is a question that will probably not find much unanimity among scholars, critics and readers. A judgment of "adequacy," a term some may feel bound to use for lack of a better one, will inevitably be based on a variety of purposes and expectations, along with a myriad of other subjective and evaluative criteria. In the case of puns, the point is not to determine whether a translation solution is adequate or inadequate, but to appreciate the creativity of translational responses as an expressive art-form.

The question of adequacy might be more constructive and relevant in the context of Pelevin's puns if rephrased into three other questions: "can a translation be considered adequate if chunks of the original text have been omitted?" and "can a translation be considered adequate if it has not been done from the original language but from another translation?," and, lastly, "should the reader be left in the dark about such things?" An intuitive response to these questions will probably be negative in all three cases. But, as my comparative readings reveal, such translations not only exist but may also be justified by the purely economic logic that "the gain outweighs the loss" or "better some Pelevin than no Pelevin at all."

"Can omission be seen as an indicator of untranslatability?" is another question that merits further discussion. Although I myself have tended to equate, perhaps erroneously, omissions with untranslatability, they alone probably cannot be a decisive factor in determining the translator's inability to find a solution, even if patterns of omission across languages and retranslations occur. In hindsight, omissions are not very conducive to analysis (unless, of course, one can interview the translator) because reasons behind them may vary. They can be deliberate or unintentional, and not always the translator's call or fault. Moreover, omissions alone cannot tell us if the pun could not be identified or, conversely, could not be captured in a satisfactory manner in translation. As Delabastita (2004: 870) points out, the identification of puns by the translator may not be taken for granted because of the possibility of either overlooking or "overreading." If a pun (especially one based on intertextual allusions) has not been identified due to oversight or lack of erudition, it is pure speculation to start imagining what the translator could or could not do with it. Across the five languages of translation in my examples, there was only one case, the "Piaget/PeZhe" exchange, when the pun was omitted in all the translations. It would be safe to assume that this particular omission points to the difficulty in deciphering (or researching) the source text. While only a decade ago, knowing who "Gospodin PeZhe" was 
would have required an acquaintance with Daneliia's film, today a simple Google search quickly produces a direct reference and a starting point for the translator.

The more well-known and accessible intertextual pun alluding to Pushkin's Eugene Onegin, which was recognized by all the translators in my examples, suggests that almost any move on the translator's part-whether an ingenious pun (like Rojewska-Olejarczuk's) or a slightly simpler one (like Bromfield's) or an idiomatic reworking (like Tretner's) or even an explicatory translation that acknowledges the joke (despite ruining it) — could go a long way toward a refutation of untranslatability. The same is true about the "Lethe/winter" and "mushrooms/coffins" puns. While Bromfield, Prieto, and Ackerman and Lorrain either omit or, at best, paraphrase or explain them, Rojewska-Olejarczuk and Tretner switch their researcher's and writer's hats - two roles that translators inevitably combine while also being, as Spivak (2012 [1993]) famously stressed, the most intimate readers - to come up with interesting creative solutions.

While the Piaget/PeZhe example illustrates how intertextuality may create obstacles for translators, the "Lethe/winter" and "mushrooms/coffins" examples show how intertextuality can also make translation possible. To view or understand translation itself as a further intertext rather than as "an equivalent of" or "an approximation to" the original (see Paz 2002 and Eagleton $1977^{6}$ ) opens up the most productive line of reasoning against untranslatability. The intertext, as a resource for possible solutions and a product resulting from the process of translation, both liberates and empowers translators confronted with challenges such as wordplay. We can see this by watching how Tatarsky translates and adapts punny advertising slogans in Pelevin's novel: he is portrayed as relying almost entirely on serendipitous intertextual epiphanies and accidental intuitive discoveries rather than on a carefully premeditated and structured decision-making process. This is not, of course, to advocate for an unconditional extrapolation of fictional findings to real-life practice or theory, but to call for a more careful observation of how the fictional conflation of the imagined and the real may usefully inform our thinking about translation.

The issues of translation ethics and translation-related linguistic and cultural hegemony come to the fore in the discussion, in the fifth example above, of Tatarsky's slogans for god, which Pelevin purportedly had to rewrite in Russian and which Bromfield then ended up reworking completely in his English version. Rojewska-Olejarczuk's very close approach makes sense considering the proximity between Russian and Polish. Tretner, on the other hand, translates the poster descriptions from Russian into German but transplants the slogans themselves into his translation from Bromfield's English version of the novel. This is a plausible strategy, given the novel's constant code-switching between Russian and English, which in the German translation then becomes between German and English. In the French and Spanish translations, both slogans and poster descriptions appear to come directly from Bromfield's English. Cross-pollination (if one may call it that) between translations into different languages may of course be useful because on a practical level, translators may benefit from seeing how the same problem has been addressed in other translations. But as the comparison between the five translations makes clear, Bromfield's approach was radical and creative, whereas in the Spanish and French versions his playful slogans are reduced to mere mimicry. What is at stake here not

\footnotetext{
${ }^{6}$ According to Octavio Paz (qtd. in Bassnett 2002: 46), "[e]very text is unique and, at the same time, it is the translation of another text." Similarly, Terry Eagleton (1977: 72) claims that "[e]very text is a set of determinate transformations of other, preceding and surrounding texts of which it may not even be consciously aware."
} 
only involves translation ethics but also the phenomenon of linguistic hegemony, whereby everything is deemed translatable via one lingua franca or dominant language which can then, as both Pelevin's novel and the translations of the novel portray, further extend its hegemonic influence through the homogenizing erasure of difference and otherness.

In the end, as the examples from Pelevin's Generation " $P$ " demonstrate, (un)translatability is much more useful as an epistemological concept, one that asks how something can be translated, providing close readings of the most difficult cases of translation so as to challenge translators to be audacious in their innovation and experimentation, than it is useful as an ontological concept, which in asking if something can be translated, merely confronts us with the paradox of the simultaneous possibility and impossibility of translation, a paradox that becomes more apparent upon comparing translations into multiple languages.

The problem of (un)translatability is central to the discipline of translation studies and crucial to the practice of translation because it posits the possibility of what translators do and what translation scholars study. It is thus only natural that the belief in ultimate translatability, in its milder or stronger version, retains its currency among both theoreticians and practitioners. In fact, my earlier statement that any creative solution on the translator's part should be appreciated regardless of its "adequacy" betrays this belief, too. At the same time, Apter's (2014: 8) caveat against the unconditional acceptance of translatability as the foundation of world literature remains very important. She writes, "With translation assumed to be a good thing en soi-under the assumption that it is a critical praxis enabling communication across language, cultures, time periods, and disciplines - the right to the Untranslatable was blindsided". The example of Pelevin's transmetic puns, based on a performance of an act of translation that reflects its own (un)translatability, brings our focus back to the untranslatable and gives hope that this debate will continue. And if it does, translation will continue being an art and not simply a craft, and translators will be challenged to experiment bravely and to dare to be, in Levine's (2009: 14-15) words, "tinkerer[s] with a musical ear," traitors, and translooters because only spunky translooters will take on translations not just because of their necessity but primarily because of their impossibility.

\section{References}

Ackerman, G. \& Lorrain, P., translators. (2001). Homo Zapiens: [roman]. By Viktor Pelevine [Viktor Pelevin]. Paris: Éditions du Seuil.

Apter, E. (2013). Against World Literature: On the Politics of Untranslatability. London: Verso. Attridge, D. (2009). 'Unpacking the portmanteau; or, who's afraid of Finnegans Wake?'. In Bloom, H. (ed.), Blooms Modern Critical Views: James Joyce, New Edition, New York: Chelsea House, pp. 5-24.

Baer, B. (2011). 'Translation theory and cold war politics: Roman Jakobson and Vladimir Nabokov in 1950s America'. In Baer, B. (ed.), Contexts, Subtexts and Pretexts: Literary Translation in Eastern Europe and Russia. Amsterdam: John Benjamins Publishing Company, pp. 171-186.

Bassnett, S. (2002). Translation Studies. $3^{\text {rd }}$ edition. London, New York, Routledge.

Beckett, S. (2009). Murphy. London: Faber and Faber.

Beebee, T. (2012). Transmesis: Inside Translation's Black Box. New York: Palgrave Macmillan. 
Blake, G. (2012). A Freudian Slip is When you Say One Thing but Mean your Mother: 879 Funny, Funky, Hip, and Hilarious Puns. New York: Skyhorse Publishing.

Blasing, M. (1995). Politics and Form in Postmodern Poetry: O'hara, Bishop, Ashbery, and Merrill. Cambridge: Cambridge University Press.

Bromfield, A., translator. (2002). Homo Zapiens by Viktor Pelevin. New York: Viking.

Culler, J. (1988). 'The call of the phoneme: introduction'. In Culler (ed.), On Puns: The Foundation of Letters. London: Basil Blackwell, pp. 1-16.

Davis, K. 'Signature in translation'. (1997). In Delabastita, D. (ed.), Traductio: Essays on Punning and Translation. Manchester: St. Jerome Publishing, pp. 23-43.

Delabastita, D. (1993). There's a Double Tongue: An Investigation into the Translation of Shakespeare's Wordplay, with Special Reference to Hamlet. Amsterdam: Rodopi.

Delabastita, D. (1996). 'Introduction'. Wordplay and Translation, special issue of The Translator 2(2), pp. 127-139.

Delabastita, D. (2004). '88. Literary style in translation: wordplay.' In Kittel, H. et al. (eds.), Übersetzung - Translation - Traduction. Teilband 1: Ein Internationales Handbuch Zur Übersetzungsforschung $=$ an International Encyclopedia of Translation Studies = Encyclopédie International De La Recherche Sur La Traduction. Berlin: Walter de Gruyter \& Co.

Derrida, J. (1986). 'Proverb: "He that would pun.'” In Leavey, J, Ulmer, G, \& Derrida, J. (authors), Glassary. Lincoln, Nebraska: University of Nebraska Press.

Derrida, J. (1985). 'Des tours de Babel'. In Graham, J. (ed.), Difference in Translation. Ithaca: Cornell University Press, pp. 165-207.

Eagleton, T. (1977). 'Translation and Transformation'. Stand 19(3), pp. 72-77.

Freud, S. (2002). The Joke and Its Relation to the Unconscious. Translated by Joyce Crick. London: Penguin.

Gruner, C. (1997). The Game of Humor: A Comprehensive Theory of Why We Laugh. New Brunswick, N.J: Transaction Publishers.

Hermans, T. (2009). 'Translatability', in Baker, M. \& Saldanha, G. (eds.), Routledge Encyclopedia of Translation Studies, London: Routledge, pp. 300-303.

Ivashkiv, R. (2018). 'Transmesis in Viktor Pelevin's Generation 'P' and Andrew Bromfield's English Translation'. Translation Studies, 11(2), pp. 201-216.

Jakobson, R. (2000). 'On linguistic aspects of translation'. In Venuti, L. (ed.), The Translation Studies Reader, London: Routledge, pp. 113-118.

Johnston, C., translator. (1979). Eugene Onegin. By Aleksandr Pushkin. New York: Penguin Books. Retrieved from 1 September 2018 from http://lib.ru/LITRA/PUSHKIN/ENGLISH/onegin j.txt.

Kjerkegaard, S. (2011). 'Seven days without a pun makes one weak. Two functions of wordplay in literature and literary theory'. Journal of Literature, Language and Linguistics 3(1), pp. $1-9$.

Koestler, A. (1964). The Act of Creation. Oxford: Macmillan.

Levine, S. J. (2009). The Subversive Scribe: Translating Latin American Fiction. Champaign, IL: Dalkey Archive Press.

Lipovetsky, M. (1999). 'Goluboe salo pokoleniia, ili Dva mifa ob odnom krizise' [Blue porklard of the generation, or two muths about one crisis]. Znamia, vol. 11. Zhurnalnyi Zal Retrieved 1 October 2018 from http://magazines.russ.ru/znamia/1999/11/lipovec.html. 
Partington, A. (2006). The Linguistics of Laughter: A Corpus-Assisted Study of Laughter-Talk. London: Routledge.

Pelevin, V. (2003). 'Viktor Pelevin: istoriia Rossii - eto prosto istoriia mody. [Viktor Pelevin: the history of Russia is simply a history of fashion]." Interview. "Park Kultury.", $\begin{array}{llllll}\text { Gazerta.ru. } & \text { Retrieved } & 1 & \text { September } & 2018 \text { from }\end{array}$ www.gazeta.ru/2003/09/02/viktorpelevi.shtml.

Pelevin, V. (2003). Generation " $P$ " [Generation "P"]. In Pesni tsarstva "ia" [Songs of the Kingdom "I"]. Moskva: Vagrius.

Polotovskii, S. \& Kozak, R. (2012). Pokoleniie Pustoty [A Generation of Emptiness]. Moscow: Mann, Ivanov i Ferber.

Prieto, J., translator. (2003). Homo Zapiens. By Viktor Pelevin. Barcelona: Mondadori.

"pun, n.1." (2018). OED Online. Oxford University Press. Retrieved 20 October 2018 from http://www.oed.com/view/Entry/154549?result=1\&rskey=cp3VUd\&.

Pursglove, M. (2008). 'Dulcis fumus patriae: Tiutchev, Turgenev and smoke.' In Andrew, J., Offord, D., \& Reid, R. (eds.), Turgenev and Russian Culture: Essays to Honour Richard Peace, Amsterdam - New York: Rodopi, pp. 285-300.

Pushkin, A. (1833). Roman v stikhakh Evgenii Onegin [Novel in verse Eugene Onegin]. Retrieved 1 September 2018 from http://www.poetry-classic.ru/8-13.html.

Redfern, W. (1985). Puns. Oxford, UK: Blackwell.

Rodnianskaia, I. (1999). 'Etot mir priduman ne nami' [This world was not invented by us]. Novyi Mir, vol. 8. Zhurnalnyi Zal, Retrieved 1 October 2018 from http://magazines.russ.ru/novyi mi/1999/8/rodnyan.html.

Rojewska-Olejarczuk, E., translator. (2002). Generation P'. By Wiktor Pieliewin [Viktor Pelevin]. Warszawa: Wydawnictwo W.A.B.

Sander, E. (2014). Lost in Translation: An Illustrated Compendium of Untranslatable Words from Around the World. Berkeley, California: Ten Speed Press.

Spivak, G. Ch. (2012). 'The politics of translation.' In Venuti, L. (ed.), The Translation Studies Reader, London: Routledge, pp. 312-331.

Tartakovsky, J. 'Pun for the ages'. The New York Times. Retrieved October 12018 from https://www.nytimes.com/2009/03/28/opinion/28Tartakovsky.html.

Tretner, A., translator. (2000). Generation P. By Viktor Pelewin [Pelevin]. Berlin: Verlag Volk and Welt.

Ulmer, G. (1988). 'The puncept in grammatology'. In Culler, J. (ed.), On Puns: The Foundation of Letters. London: Basil Blackwell, pp. 164-189.

Venuti, L. (2014). 'Translation, intertextuality, interpretation.' Romance Studies, 27(3), pp. 157173.

Vinokur, V. \& Réjouis, R. (2018). 'On collaborative translation'. In Levine S.J. \& Lateef-Jan, K. (eds.), Untranslatability Goes Global. New York, London: Routledge.

"wordplay, n" (2018). OED Online. Oxford University Press. Retrieved 20 October 2018 from

http://www.oed.com/view/Entry/230192?redirectedFrom=wordplay\#eid14318694. 